\title{
Quality-of-Life in Turkish Cancer Patients: The Impact of Sociodemographic Characteristics, Medical History, and Management
}

\author{
Tayfur TOPTAS ${ }^{1}$, Ibrahim YILDIZ ${ }^{2}$, Melek YILDIZ ${ }^{3}$, Umut VAROL ${ }^{2}$, \\ Ibrahim V. BAYOGLU ${ }^{2}$, Mustafa OZGUROGLU ${ }^{4}$ \\ ${ }^{1}$ Van Territorial Training and Research Hospital, Department of Haematology, Van \\ ${ }^{2}$ Izmir Katip Celebi University, Ataturk Training and Research Hospital, Department of Medical Oncology, Izmir \\ ${ }^{3}$ Dr. Behçet Uz Children Training and Research Hospital, Department of Pediatric Endocrinology, Izmir \\ ${ }^{4}$ Istanbul University, Cerrahpasa Medical Faculty, Department of Medical Oncology, Istanbul, TURKEY
}

\begin{abstract}
Our aim is to assess the quality-of-life (QoL) of cancer patients and the effect of sociodemographic characteristics, medical history, and disease management, on QoL. The present study included 318 cancer patients. The most common diagnosis in this study were breast cancer (30.0\%) and gastrointestinal cancer (27.7\%). A form exploring sociodemographic variables and the EORTC QLQ-C30 questionnaire were used to collect patient data. Non-parametric tests were employed to evaluate the association of different factors with patient QoL. Sociodemographic characteristics such as age; gender; level of education; employment status; and medical history, including any family history of cancer, date of diagnosis, cancer awareness, stage of the disease, past/current treatments, use of painkillers, and psychiatric support, significantly affected the QoL of cancer patients. The mean QoL score was moderate $(56.05 \% \pm 26.42)$. Physical functioning was the most affected subdomain (63.27 \pm 25.69$)$, and cognitive functioning the least affected $(78.35 \pm 23.47)$. Our results indicate a relationship between many clinical and sociodemographic factors and the QoL of cancer patients. Healthcare professionals should be aware of factors that affect QoL so that patient complaints and needs can be adequately addressed to improve patient QoL.
\end{abstract}

Keywords: Cancer, Clinical factors, Medical history; Quality-of-life, Sociodemographic factors

\section{ÖZET}

Türk Kanser Hastalarında Sosyodemografik Karakteristiklerin, Tıbbi Öykünün ve Tedavilerin Yaşam Kalitesi Üzerine Etkisi

Bu çalışmanın amacı kanser hastalarında yaşam kalitesini değerlendirmek ve sosyodemografik karakteristiklerin, tıbbi öykünün ve tedavilerin yaşam kalitesi üzerine etkilerini araştırmaktır. Çalışmamız 318 kanser hastasından oluşmaktadır. En sık görülen tanı meme kanseri (\%30.0) ve gastrointestinal kanserdir (\%27.7). Yaşam kalitesi verileri için EORTC QLQ-C30 anketi ve sosyodemografik değişkenleri içeren formlar kullanılmıştır. Hastaların yaşam kalitesine etki eden faktörleri değerlendirmek için non-parametrik testlerden faydalanılmıştır. Yaş; cinsiyet; meslek; eğitim durumu; tıbbi ve aile öyküsü de içeren sosyodemografik veriler, tanı tarihi, hastalık evresi, kanser farkındalığı, tedaviler, ağrı kesici kullanımı ve psikiyatri desteğinin kanser hastalarının yaşam kalitesini anlamlı biçimde etkilediği saptanmışır. Hastaların ortalama yaşam kalitesi skoru (56.25 \pm 26.42 ) orta derecededir. Fiziksel fonksiyonlar en fazla etkilenen (63.27 \pm 25.69$)$, bilişsel fonksiyonlar ise en az etkilenen (78.35 23.47$)$ alt grubu oluşturmaktadır. Çalısmamızda birçok klinik ve sosyodemografik faktörün kanser hastalarının yaşam kalitesine etki ettiği gözlenmiştir. Sağık çalışanlarının bu faktörlerin farkında olmaları, kanser hastalarıın şikayetlerinin ve intiyaçlarının çözümlenebilmesi açısından önem taşımaktadır.

Anahtar Kelimeler: Kanser, Klinik faktörler, Tıbbi öykü, Yaşam kalitesi, Sosyodemografik faktörler 


\section{INTRODUCTION}

Clinicians define the quality-of-life (QoL) of a patient as satisfaction with his or her current level of functioning relative to what is perceived to be possible or ideal. ${ }^{1,2}$ In particular, QoL reflects a patient's perceptions and thoughts on his or her life, employing self-defined objectives, expectations, standards, and preferences. QoL is a multidimensional construct that includes perceptions of positive and negative aspects of physical, emotional, social, and cognitive functioning, and also considers somatic discomfort and other symptoms caused by disease or treatment. ${ }^{2}$

Significant efforts have been made to improve patient QoL. In particular, numerous factors associated with cancer and cancer therapies can affect QoL. The aim of the present study was to assess the QoL of Turkish cancer patients and to identify factors affecting QoL.

\section{PATIENTS and METHODS}

Our study included consecutive patients who were diagnosed and followed-up for at least 2 months, in medical wards and outpatient clinics of Istanbul University, including the Institute of Oncology, the Department of Medical Oncology, and the Department of Radiation Oncology (Istanbul, Turkey). Patients were briefed on study aims and told of questionnaires to be completed; they were informed that they could decline to participate at any time by simply refusing to complete forms or requesting that questionnaires not be used for analysis. After providing written informed consent, all patients were asked to complete a sociodemographic questionnaire and the Quality of Life C30 Questionnaire (QLQ-C30). Some sociodemographic questionnaires were completed with the help of a physician if a patient requested such assistance. All QLQ-C30s were completed by patients without any help. Patients in the pre-terminal period and those with serious life-threatening conditions were excluded. In total, 430 cancer patients were initially enrolled, but only 318 patients completed the study. Our study protocol was approved by the Istanbul University Ethical Review Board. All patients provided written informed consent.

The Patient Information Form was used to collect the following data: sociodemographic information (age, gender, level of education, job, place of birth, place of residence, health insurance status, employment status, and mode of transportation to the hospital); medical history (diagnosis, date of diagnosis, disease stage at diagnosis, current disease stage, accompanying diseases, past and current treatments, and family history of cancer); awareness of diagnosis; and use of sleeping pills, antidepressants, and painkillers. Quality-of-life was assessed using the EORTC QLQC30 (version 3.0), a 30-item self-rating questionnaire with subscales that evaluate physical (five items), emotional (four items), role (two items), cognitive (two items), and social (two items) functioning, as well as global health status (two items). Higher subscale scores indicate a higher level of functioning. The QLQ-30 also includes three symptom subscales assessing the extent of nausea and vomiting (two items), fatigue (three items), and pain (two items); and six single items that assess the financial impact and various physical symptoms of disease. Higher symptom scale/single item scores indicate more severe symptomatology.

SPSS version 15.0 was used for data analysis. Descriptive statistics were employed, and means, medians, frequencies, and percentages were used to characterize the distribution of sociodemographic characteristics, medical management and history, and QoL. The Mann-Whitney U, Kruskal-Wallis, and Spearman's Rho correlation tests were employed to assess the impact of sociodemographic characteristics, medical management, and history, on QoL. In all statistical analyses, a two-sided p-value less than 0.05 were considered statistically significant.

\section{RESULTS}

The study group consisted of 318 patients, 131 males (41.2\%) and 187 females (58.8\%), of mean age 50.39 \pm 12.96 years (range: $18-78$ years). All patients were at least 18 years of age. Most patients (66.4\%) were middle-aged (35-59 years of age), $49.1 \%$ had 1-9 years of formal education, $74.8 \%$ were married, and $78.9 \%$ were employed (Table 1).

When asked if they understood their diagnosis, $95.6 \%$ answered in the affirmative, although only $82.4 \%$ cited the diagnosis correctly. The most common diagnoses in the study group were breast cancer (30.0\%) and gastrointestinal (GI) cancer (27.7\%). Cancer staging at the time of diagnosis indicated that $31.7 \%$ had stage $1-2$ disease, $34 \%$ stage 3 disease, and $34.3 \%$ stage 4 disease. The median time from diagnosis was 13 months (range: 2-144 months). At some point during treatment, $87.5 \%$ of patients received chemotherapy and $46.1 \%$ radiotherapy (Table 2 ). 
Table 1. Sociodemographic characteristics of enrolled cancer patients $(n=318)$

\begin{tabular}{|c|c|c|}
\hline & $\mathbf{n}$ & $\%$ \\
\hline \multicolumn{3}{|l|}{ Age (years) } \\
\hline $18-34$ & 32 & 10.1 \\
\hline $35-59$ & 211 & 66.4 \\
\hline $60-89$ & 75 & 23.6 \\
\hline \multicolumn{3}{|l|}{ Gender } \\
\hline Male & 131 & 41.2 \\
\hline Female & 187 & 58.8 \\
\hline \multicolumn{3}{|l|}{ Education } \\
\hline Illiterate & 11 & 3.5 \\
\hline Primary-middle School & 156 & 49.1 \\
\hline High-school & 76 & 23.9 \\
\hline University & 75 & 23.6 \\
\hline \multicolumn{3}{|l|}{ Marital status } \\
\hline Married & 238 & 74.8 \\
\hline Single & 41 & 12.9 \\
\hline Widowed or divorced & 39 & 12.3 \\
\hline \multicolumn{3}{|l|}{ Employment Status } \\
\hline Working & 66 & 21.1 \\
\hline Not working & 247 & 78.9 \\
\hline
\end{tabular}

The mean QoL score was moderate $(56.05 \pm 26.42)$. Physical functioning was the most affected subdomain $(63.27 \pm 25.69)$, and cognitive functioning the least affected $(78.35 \pm 23.47)$. The most common complaints were lethargy, economic hardship, and sleep disturbance. The least reported symptoms were nausea and vomiting, followed by dyspnea and diarrhea (Table 3).

We also assessed the association between sociodemographic characteristics, and medical history and management, on QoL. Patient age, gender, level of education, and employment status were all associated with QoL. In addition, medical history and management, a family history of cancer, date of diagnosis, cancer awareness, disease stage, past and current treatments, use of painkillers, and psychiatric support were also associated with QoL.

Patient age was associated with the severity of lethargy, dyspnea, and diarrhea, and a decreased level of physical functioning (Table 4). Cognitive functioning was more adversely affected in female patients $(\mathrm{p}=$ 0.001 ) and financial status was more adversely af-
Table 2. Disease characteristics of cancer patients $(n=318)$

\begin{tabular}{|c|c|c|}
\hline & $\mathbf{n}$ & $\%$ \\
\hline \multicolumn{3}{|l|}{ Diagnosis } \\
\hline Breast Cancer & 93 & 30.0 \\
\hline GIS Cancers & 86 & 27.7 \\
\hline Hematological Cancers & 20 & 6.5 \\
\hline Gynecological Cancers & 33 & 10.6 \\
\hline Lung Cancer & 23 & 7.4 \\
\hline Brain Cancer & 6 & 1.9 \\
\hline Prostate Cancer & 4 & 1.3 \\
\hline Musculoskeletal Cancers & 12 & 3.9 \\
\hline Malign Melanoma & 6 & 1.9 \\
\hline Testicular Cancer & 11 & 3.5 \\
\hline Other & 16 & 5.2 \\
\hline \multicolumn{3}{|l|}{ Stage at diagnosis } \\
\hline Stage 1-2 & 84 & 31.7 \\
\hline Stage 3 & 90 & 34.0 \\
\hline Stage 4 & 91 & 34.3 \\
\hline \multicolumn{3}{|l|}{ Family history of cancer } \\
\hline Yes & 128 & 45.6 \\
\hline No & 153 & 54.4 \\
\hline \multicolumn{3}{|l|}{ Disease awareness } \\
\hline Yes & 304 & 95.6 \\
\hline No & 14 & 4.4 \\
\hline \multicolumn{3}{|c|}{ Patient knowledge of correct diagnosis } \\
\hline Yes & 262 & 82.4 \\
\hline No & 56 & 17.6 \\
\hline \multicolumn{3}{|l|}{ Chemotherapy } \\
\hline Previously & 85 & 27.2 \\
\hline Within the last 3 months & 188 & 60.3 \\
\hline No & 39 & 12.5 \\
\hline \multicolumn{3}{|l|}{ Radiotherapy } \\
\hline Previously & 96 & 32.3 \\
\hline Within the last 3 months & 41 & 13.8 \\
\hline No & 160 & 53.9 \\
\hline
\end{tabular}

fected in males $(\mathrm{p}=0.02)$. Those with high-school or higher levels of education were more likely to exhibit better physical, role, and emotional functioning than were those who were only primary school graduates $(p=0.01)$. In addition, primary school graduates were 
Table 3. Patient quality of life (QOL) scores $(n=318)$.

\begin{tabular}{|c|c|c|c|c|c|}
\hline & Median & Mean & $\begin{array}{l}\text { Standard } \\
\text { Deviation }\end{array}$ & Minimum & Maximum \\
\hline Global QoL* & 58.33 & 56.05 & 26.42 & .00 & 100.00 \\
\hline \multicolumn{6}{|l|}{ Functional Scales } \\
\hline Physical Functioning* & 66.67 & 63.27 & 25.69 & .00 & 100.00 \\
\hline Role Functioning* & 83.33 & 70.07 & 34.11 & .00 & 100.00 \\
\hline Emotional Functioning* & 75.00 & 69.16 & 26.09 & .00 & 100.00 \\
\hline Cognitive Functioning ${ }^{\star}$ & 83.33 & 78.35 & 23.47 & .00 & 100.00 \\
\hline Social Functioning* & 66.67 & 68.08 & 31.56 & .00 & 100.00 \\
\hline \multicolumn{6}{|c|}{ Symptom and Side-Effect Scale Scores, and Item Scores } \\
\hline Lethargy ${ }^{\star *}$ & 44.44 & 49.65 & 28.66 & .00 & 100.00 \\
\hline Nausea and Vomiting ${ }^{\star \star}$ & 16.67 & 23.48 & 27.81 & .00 & 100.00 \\
\hline Pain $^{\star \star}$ & 33.33 & 35.80 & 31.05 & .00 & 100.00 \\
\hline Dyspnea* & 00.00 & 22.12 & 32.70 & .00 & 100.00 \\
\hline Sleep Disturbance ${ }^{\star \star}$ & 33.33 & 35.85 & 34.63 & .00 & 100.00 \\
\hline Appetite Loss ${ }^{\star \star}$ & 00.00 & 27.57 & 33.98 & .00 & 100.00 \\
\hline Constipation ${ }^{\star \star}$ & 33.33 & 31.97 & 32.99 & .00 & 100.00 \\
\hline Diarrhea** & 00.00 & 18.45 & 28.43 & .00 & 100.00 \\
\hline Financial Distress ${ }^{\star \star}$ & 33.33 & 36.90 & 33.72 & .00 & 100.00 \\
\hline
\end{tabular}

more likely to have experienced financial hardship $(p=0.01)$. Patients who were not working experienced lower global QoL $(\mathrm{p}=0.008)$, poorer physical functioning $(\mathrm{p}=0.001)$, more lethargy $(\mathrm{p}=0.0049)$, and more constipation $(\mathrm{p}=0.04)$.

Patients with family histories of cancer suffered from more sleep disturbance $(\mathrm{p}=0.004)$. Moreover, as the post-diagnosis period increased, the adverse effect on physical functioning was more severe (Table 4). All QoL subdomains in stage 4 cancer patients (physical functioning [ $\mathrm{p}=0.003]$, role functioning $[\mathrm{p}=0.001]$, emotional functioning $[p=0.02]$, cognitive functioning $[p=0.009]$, and social functioning $[p=0.0001])$, as well as lethargy $(\mathrm{p}=0.02)$, constipation $(\mathrm{p}=0.01)$, nausea and vomiting $(\mathrm{p}=0.007)$, dyspnea $(\mathrm{p}=0.01)$, sleeping disorders $(\mathrm{p}=0.003)$, and financial hardship $(\mathrm{p}=0.01)$, became more strongly affected.

Patients who received chemotherapy within the last 3 months were more likely to report adverse effects on role $(\mathrm{p}=0.002)$ and social functioning $(\mathrm{p}=0.001)$, and to have more frequently experienced lethargy $(\mathrm{p}=0.004)$, nausea and vomiting $(\mathrm{p}=0.03)$, and loss of appetite $(p=0.01)$. Patients who did not receive radiotherapy tended to have a higher level of physical functioning $(p=0.01)$. Patients who had received radiotherapy within the last 3 months had a lower global QoL $(\mathrm{p}=0.01)$, role perception $(\mathrm{p}=0.0001)$, and cognitive functioning $(\mathrm{p}=0.03)$, and experienced lethargy more frequently $(\mathrm{p}=0.02)$.

Patients who used painkillers had a lower global QoL ( $\mathrm{p}=0.0001)$; and a lower level of physical $(\mathrm{p}=$ $0.0001)$, role $(\mathrm{p}=0.0001)$, emotional $(\mathrm{p}=0.0001)$, and cognitive functioning ( $\mathrm{p}=0.002)$; and more frequently experienced lethargy $(\mathrm{p}=0.0001)$, nausea and vomiting $(\mathrm{p}=0,02)$, pain $(\mathrm{p}=0.0001)$, dyspnea $(\mathrm{p}=$ $0.0001)$, loss of appetite $(\mathrm{p}=0.0001)$, constipation $(\mathrm{p}=$ $0.0001)$, and sleeping disorders $(\mathrm{p}=0.0001)$. Patients who sought psychiatric treatment had a lower level of emotional functioning $(\mathrm{p}=0.001)$, were more adversely affected in terms of cognitive functioning ( $\mathrm{p}=$ $0.003)$, and had more sleeping disorders $(\mathrm{p}=0.01)$. 


\begin{tabular}{|c|c|c|c|c|}
\hline \multirow[t]{2}{*}{ Age (years) } & \multicolumn{4}{|c|}{ Post-diagnostic interval (months) } \\
\hline & rs & $\mathrm{R}$ & rs & $P$ \\
\hline Global QoL & -0.08 & 0.15 & 0.01 & 0.81 \\
\hline \multicolumn{5}{|l|}{ Functional Scales } \\
\hline Physical Functioning & -0.15 & 0.005 & -0.19 & 0.001 \\
\hline Role Functioning & -0.02 & 0.69 & 0.04 & 0.40 \\
\hline Emotional Functioning & 0.05 & 0.31 & -0.04 & 0.49 \\
\hline Cognitive Functioning & 0.02 & 0.71 & -0.07 & 0.18 \\
\hline Social Functioning & 0.12 & 0.03 & 0.01 & 0.78 \\
\hline \multicolumn{5}{|c|}{ Symptom and Side-Effect Scale Scores, and Item Scores } \\
\hline Lethargy & 0.15 & 0.006 & 0.03 & 0.53 \\
\hline Nausea and Vomiting & -0.12 & 0.03 & -0.01 & 0.81 \\
\hline Pain & -0.02 & 0.62 & -0.03 & 0.50 \\
\hline Dyspnea & 0.18 & 0.001 & 0.11 & 0.05 \\
\hline Sleep Disturbance & 0.11 & 0.05 & -0.05 & 0.37 \\
\hline Appetite Loss & 0.04 & 0.45 & -0.01 & 0.74 \\
\hline Constipation & 0.01 & 0.76 & 0.04 & 0.40 \\
\hline Diarrhea & 0.15 & 0.005 & 0.05 & 0.32 \\
\hline Financial Distress & -0.10 & 0.05 & -0.01 & 0.79 \\
\hline
\end{tabular}

\section{DISCUSSION}

Medical studies evaluating the effectiveness of treatment increasingly use QoL as a primary outcome measure, ${ }^{3-5}$ and the EORTC QLQ-C30 is the most widely used instrument measuring the QoL of cancer patients. The present study evaluated the impact of sociodemographic, medical, and psychosocial variables on the QoL of cancer patients who were being followed-up at Istanbul University. Females were more likely to report adverse effects on cognitive functioning, and males more likely to report financial hardship. However, in agreement with the findings of previous reports, ${ }^{6}$ no other significant gender-specific difference in QoL was apparent. Older patients were more likely to report poorer physical functioning and the presence of lethargy, dyspnea, and diarrhea.

In the present study, patients who were not working had a lower global QoL and poorer physical functioning, and were more likely to report lethargy and constipation. This may be because severely ill patients were less likely to work because of the severity of disease or the presence of disease-related psychological problems. More patients with positive family histories of cancer experienced sleeping disorders, pos- sibly because of pessimism associated with having a serious disease previously experienced by another family member.

Interestingly, we found a higher level of physical, role, and emotional functioning in patients who were high-school and college graduates than in those who were less educated. Symptoms such as nausea and vomiting, pain, loss of appetite, diarrhea, dyspnea, lethargy, and financial hardship, were more common in primary and secondary school graduates, possibly because such patients are less able to manage personal symptoms and functions and cannot easily adapt as cancer progresses. It seems likely that better-educated patients were more aware of and had had better access to social support systems.

Patients with any stage of cancer can experience poor QoL. ${ }^{6,7}$ In our present study, patients with stage 4 disease experienced lower physical, role, and emotional functioning; were more adversely affected in terms of cognitive and social functioning; and had more symptoms (lethargy, nausea, vomiting, dyspnea, constipation, and sleeping disorders) than did stage 2-3 patients. In other words, patients with more advanced cancer had a worse QoL, as might be expected. 
Patients who received chemotherapy within the last 3 months were more likely to experience adverse effects in terms of role and social functioning, and were more likely to report lethargy, nausea and vomiting, and loss of appetite, than were patients who did not receive such chemotherapy. This is likely attributable to the toxic effects of chemotherapy. Patients who received radiotherapy in the last 3 months had a lower global QoL and role functioning scores, and were more likely to report lethargy and constipation than were patients who did not receive such radiotherapy, or who had undergone such therapy formerly. Again, this is likely attributable to the toxic effects of radiotherapy. In agreement with our findings, a previous study reported that patients diagnosed with cancer who were treated with chemotherapy or radiotherapy reported a worse QoL, and experienced more severe disruption of physical, emotional, social, and financial functions. ${ }^{8}$

Cancer patients often fear pain ${ }^{9,10}$; this is associated with disruption of cognitive, motivational, affective, psychological, and physical factors. ${ }^{11}$ In addition, uncontrolled pain may adversely affect survival. In our present study, patients taking painkillers had lower global QoL, cognitive, physical, role, and emotional functioning scores, and were more likely to report lethargy, nausea and vomiting, pain, dyspnea, loss of appetite, constipation, and sleeping disorders. This indicates that use of painkillers affects a wide spectrum of factors relevant to QoL.12 However, limitations in the control of cancer pain are evident; these are linked to the roles played by healthcare workers, the healthcare system, and patients per se. ${ }^{13,14}$ In terms of pain management, inappropriate approaches can be minimized via education and QoL can be increased..$^{15-17}$

In daily practice, cancer patients with emotional or cognitive function problems are more likely to complain of nausea and vomiting, pain, dyspnea, sleeping disorders, and constipation; and to seek psychiatric treatment. We observed lower global QoL, poorer emotional functioning, adverse effects on cognitive functioning, and a higher frequency of symptoms (pain, sleeping disorders, and constipation) in patients who used antidepressants. This may be because the drugs are ineffective or the symptoms may be attributable to drug side-effects.

Previous work showed that the prevalence of elevated psychosocial distress in patients with cancer at diagnosis and recurrence was about $30 \%, 18$ and that clinical depression was evident in about $25 \%$ of such patients.19 In the present study, $14.8 \%$ of our cancer patients used antidepressants. Depression is associated with functional limitation of cancer survivors, ${ }^{20}$ and anxiety and depression can independently worsen functional and overall health..$^{21,22}$ Effective management of depression and anxiety in cancer patients may positively affect other outcomes ${ }^{23}$ such as global health, cognitive functioning, and lethargy. ${ }^{24}$

Our present study had some limitations. We included only a relatively small number of patients with prostate cancer, because most such patients are followedup by the Urology Department of our hospital. The same was true for lung cancer patients (treated by the Respiratory Diseases Department), and head-andneck cancer patients (treated by the Ear, Nose, and Throat; or Radiation Oncology Departments). Second, some interviews were conducted in the absence of complete privacy, and this may have affected some answers given. Third, the survey was not anonymous, and some patients declined to participate because of privacy concerns.

In conclusion, cancer can have a strong negative impact on QoL. We have highlighted the consistency and strengths of relationships between clinical and sociodemographic factors and QoL in cancer patients followed-up at the University of Istanbul. We suggest that physicians consider factors that affect QoL of cancer patients so that adequate resources can be devoted to improve the patient QoL.

\section{Acknowledgements}

We thank all the patients and their families for their participation in this study and the investigators and their staffs from the participating sites.

\section{REFERENCES}

1. Billingham LJ, Abrams KR, Jones DR. Methods for the analysis of quality of life and survival data in health technology assessment. Health Technol Asess 3: 1-152, 1999.

2. Lehto US, Ojanen M, Kellokumpu-Lehtinen P. Predictors of quality of life in newly diagnosed melanoma and breast cancer patients. Ann Oncol 16: 805-816, 2005.

3. Guyatt G, Feeny DH, Patrick DL. Measuring health-related quality of life. Ann Inter Med 118: 622-629, 1993.

4. Wilson IB, Cleary PD. Linking clinical variables with health-related quality of life. A conceptual model of patient outcomes. J Am Med Ass 273: 59-65, 1995. 
5. Testa MA, Simonson DC. Assessment of quality of life outcomes. The New Eng J Med 334: 835-840, 1996.

6. Thatcher $\mathrm{N}, \mathrm{Hopwood} \mathrm{P}$, Anderson $\mathrm{H}$. Improving quality of life in patients with non-small cell lung cancer: research experience with gemcitabine. Eur J Cancer 33: 8-13, 1997.

7. Hörnquist JO. Quality of life: concept and assessment. Scand J Med 18: 69-79, 1989.

8. Greimel E, Thiel I, Peintinger F, et al. Prospective Assessment of Quality of Life of Female Cancer Patients. Gynecol Oncol 85: 140-147, 2002.

9. Pargeon KL, Hailey BJ. Barriers to Effective Cancer Pain Management: a review of the Literature. J Pain Symptom Manage 18: 358-368, 1999.

10. Howell D, Butler L, Vincent L, et al. Influencing nurse's knowledge, attitudes, and practice in cancer pain management. Cancer Nurs 23: 55-63, 2000.

11. Evans CJ, Trudeau E, Mertzanis P. Development and validation of the pain treatment satisfaction scale (PTSS): a patient satisfaction questionnaire for use in patients with chronic or acute pain. Pain 112: 254-266, 2004.

12. Tafas CA, Patiraki E, McDonald DD, Lemonidou C. Testing an instrument measuring Greek nurses' knowledge and attitudes regarding pain. Cancer Nurs 25: 8-14, 2002.

13. Cleary JF. Cancer Pain Management. Cancer Cont 7: 120131, 2000.

14. Paice JA, Toy C, Shott S. Barriers to cancer pain relief: fear of tolerance and addiction. J Pain Symptom Manage 16: 1-9, 1998.

15. Weissman DE, Dahl JL. Update on the cancer pain role model education program. J Pain Symptom Manage 10: 292-297, 1995.

16. Max MB. Improving outcomes of analgesic treatment: is education enough? Ann Intern Med 113: 885-889, 1990.

17. McCaffery M. Pain control. Barriers to the use of available information. World Health Organization Expert Committee on Cancer Pain Relief and Active Supportive Care. Cancer 70: 1438-1449, 1992.

18. Zabora JR, Blanchard CG, Smith ED, et al. Prevalence of psychological distress among cancer patients across the disease continuum. J Psychosoc Oncol 15: 73-87, 1997.
19. Pirl WF, Roth AJ. Diagnosis and treatment of depression in cancer patients. Oncology 13: 1293-1301, 1999.

20. Wang L, van Belle G, JKukull WB, Larson EB. Predictors of functional change: A longtiudinal study of nondemented people aged 65 and older. J Am Geriatr Soc 50: 1525-1534, 2002.

21. Dausch BM, Compas BE, Beckjord E, et al. Rates and correlates of DSM-IV diagnoses in women newly diagnosed with breast cancer. J Clin Psychol Med Settings 11: 159-169, 2004.

22. Simmonds MJ. Physical function in patients with cancer: Psychometric characteristics and clinical usefulness of a physical performance test battery. J Pain Symptom Manage 24: 404414, 2002

23. Ferrell $\mathrm{BR}$, Dow $\mathrm{KH}$, Leigh $\mathrm{S}$, et al. Quality of life in long-term cancer survivors. Oncol Nurs Forum 22: 915-922, 1995.

24. Smith EM, Gomm SA, Dickens CM. Assessing the independent contribution to quality of life from anxiety and depression in patients with advanced cancer. Palliat Med 17: 509-513, 2003.

\section{Correspondence}

Dr. İbrahim YILDIZ

İmir Katip Çelebi Üniversitesi

Atatürk Eğitim ve Araştırma Hastanesi

Medikal Onkoloji Bölümü

Karabağlar, IZMIR / TURKEY

Tel: (+90.232) 3434343

Fax: (+90.232) 2431530

e-mail: dr_ibrahim2000@yahoo.com 